\title{
Correction to: Cervical vestibular evoked myogenic potential and high-frequency audiometry results in Behçet's disease
}

Noha M. Abdel Baki ${ }^{1 *}$, Abeer Mohamed Ahmed Zahran', Abeir Osman Dabbous², Rabab Ahmed Koura ${ }^{3}$ and Mona Mohamed Hamdy ${ }^{2}$

\section{Correction to: Egypt Rheumatol Rehabil 48, 3 (2021) https://doi.org/10.1186/s43166-020-00052}

The original version of this article [1] unfortunately included an error to the third author's given name. Author Abeir Osman Dabbous was erroneously presented as Abeer Osman Dabbous.

The correct name is shown in the author list of this Correction and has already been updated in the original article.

\section{Author details \\ 'Department of Rheumatology and Rehabilitation, Faculty of Medicine, Cairo University, 7 Omar EbnAbiRabeah Street, El Haram, Kasr Al Ainy, Giza 12311, Egypt. ${ }^{2}$ Audiology Unit, Department of Otolaryngology, Faculty of Medicine, Cairo University, Kasr Al Ainy, Giza, Egypt. ${ }^{3}$ Audiology Unit, Department of Otolaryngology, Faculty of Medicine, Beni Suef University, Beni Suef, Egypt.}

Published online: 08 March 2021

\section{Reference}

1. Abdel Baki NM et al (2021) Cervical vestibular evoked myogenic potential

and high-frequency audiometry results in Behçet's disease. Egypt

Rheumatol Rehabil 48:3. https://doi.org/10.1186/s43166-020-00052-z

\section{* Correspondence: nohabaki@yahoo.com}

'Department of Rheumatology and Rehabilitation, Faculty of Medicine, Cairo University, 7 Omar EbnAbiRabeah Street, El Haram, Kasr Al Ainy, Giza 12311,

Egypt

Full list of author information is available at the end of the article

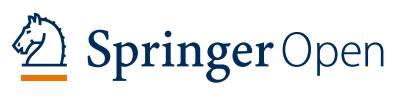

(-) The Author(s). 2021 Open Access This article is licensed under a Creative Commons Attribution 4.0 International License, which permits use, sharing, adaptation, distribution and reproduction in any medium or format, as long as you give appropriate credit to the original author(s) and the source, provide a link to the Creative Commons licence, and indicate if changes were made. The images or other third party material in this article are included in the article's Creative Commons licence, unless indicated otherwise in a credit line to the material. If material is not included in the article's Creative Commons licence and your intended use is not permitted by statutory regulation or exceeds the permitted use, you will need to obtain permission directly from the copyright holder. To view a copy of this licence, visit http://creativecommons.org/licenses/by/4.0/. 